\title{
ANALISIS IDENTIFIKASI WAJAH MENGGUNAKAN GABOR FILTER DAN SKIN MODEL
}

\author{
Khairunnisa $^{1}$, Rismayanti ${ }^{2}$, Rully Alhari ${ }^{3}$ \\ 1,2,3 Jurusan Teknik Informatika, Fakultas Teknik dan Ilmu Komputer \\ Universitas Harapan Medan, Jl. HM Jhoni No. 70 Medan, Indonesia \\ rullyalhari@gmail.com
}

\begin{abstract}
Abstrak - Identifikasi wajah pada citra digital merupakan proses yang kompleks dan membutuhkan kombinasi berbagai macam metode. Kompleksitas identifikasi wajah semakin meningkat seiring dengan meningkatnya kebutuhan akan akurasi yang tinggi terhadap citra wajah. Penelitian ini menganalisis kombinasi metode Skin Color Model dan Filter Gabor dalam proses mengidentifikasi identitas wajah pada citra digital. Metode Skin Color Model digunakan untuk memisahkan area wajah dari citra wajah berdasarkan nilai warna kulit pada citra wajah. Area wajah kemudian diekstraksi fitur nya menggunakan Filter Gabor. Penelitian ini menghasilkan akurasi paling tinggi adalah 93.6349\%. dan akurasi paling rendah berkisar 82.45\%. Implementasi kombinasi Skin Color Model dan Filter Gabor dapat menjadi salah satu metode alternatif dalam mengidentifikasi wajah pada citra digital.
\end{abstract}

Kata Kunci - Citra Digital, Identifikasi Wajah, Skin Color Model, Filter Gabor.

Abstract - The identification of faces in digital images is a complex process and requires a combination of various methods. The complexity of face identification increases with the increasing need for high accuracy on the face image. This study analyzed the combination of Skin Color Model and Filter Gabor methods in the process of identifying face identity in digital images. Skin Color Model method is used to separate facial area from face image based on skin color value in face image. The face area then extracted its features using Gabor Filter. This study yielded the highest accuracy was 93.6349\%. and the lowest accuracy ranged from 82.45\%. Implementation of combination Skin Color Model and Gabor Filter can be one of alternative method in identifying face in digital image..

Keywords - Digital Image, Face Identification, Skin Color Model, Gabor Filter.

\section{Pendahuluan}

Citra digital telah digunakan secara luas pada era modern seperti sekarang ini, citra digital banyak dimanfaatkan untuk merekam informasi, komunikasi dan lain sebagainya. Seiring berkembang luasnya pemanfaatan citra digital di hampir setiap aspek aktifitas manusia, muncul kebutuhan akan kemampuan untuk melakukan identifikasi maupun klasifikasi informasi yang terkandung pada citra digital. Beberapa tahun belakangan ini beberapa gagasan baru mengenai tujuan dan metode dari bidang pengolahan citra telah meningkat drastis, salah satu diantaranya adalah bidang pengenalan wajah atau identifikasi wajah dimana pengenalan wajah merupakan kegiatan untuk memperoleh informasi dan mengidentifikasi wajah yang terdapat pada citra digital. Identifikasi wajah pada citra digital dapat dilakukan dengan berbagai metode dan algoritma yang mana melibatkan informasi-informasi seperti warna, bentuk dan lain sebagainya. Proses identifikasi wajah yang melibatkan banyak metode dan informasi menghasilkan informasi yang cukup baik namun memiliki dampak biaya atau cost yang tidak sedikit. Beberapa penelitian menggunakan fitur warna dalam kegiatan pengenalan objek dikarenakan proses yang cepat dan sederhana [1]. Skin Model merupakan kondisi atau kriteria yang digunakan untuk membantu menentukan apakah suatu piksel memiliki nilai warna yang memenuhi syarat sebagai warna kulit atau bukan [2]. Hasil ekstraksi fitur kulit sangat membantu dalam memisahkan anggota tubuh manusia dari objek lain yang terdapat pada citra salah satunya adalah wajah. Skin Model sendiri tidak dapat langsung digunakan dalam kegiatan identifikasi wajah sehingga dibutuhkan proses tambahan seperti penggunaan Gabor Filters. Gabor Filter merupakan Filter yang diperoleh dengan memodulasi sebuah gelombang sinus dua dimenasi (2-D sine wave) yang kemudian dikonvolusikan kepada citra digital sehingga menghasilkan fitur-fitur unik dari setiap sudut filter nya. Penelitian mengenai gabor filter pada kasus pengenalan wajah dapat dilihat pada penelitian yang dilakukan oleh [3]. dan kawankawan dengan judul penelitian Face Recogition by Using Gabor Feature Extraction and Neural Networks dimana pada penelitian ini ekstraksi fitur wajah menggunakan gabor filter dan jaringan saraf tiruan mencocokkan gambar wajah inframerah dengan gambar wajah optik,Filter Gabor ini telah membuktikan diri sebagai alat yang ampuh untuk ekstraksi fitur wajah dari pola wajah tertentu, karena gambar inframerah yang ditangkap oleh perangkat pencitraan yang 
disimpulkan dan gambar optik yang ditangkap oleh perangkat pencitraan optik. Untuk mengurangi kesenjangan modalitas antara gambar inframerah dan optik, satu metode digunakan analisis diskriminan fitur umum metode ini meningkatkan kinerja pengenalan wajah inframerah-optik. Metode ini memberikan gambaran umum dari gambar wajah heterogen, (gambar wajah inframerah dan gambar wajah optik). Metode pencocokan kedua diterapkan pada fitur yang dihasilkan untuk mendapatkan hasil yang maksimal [4].

Penelitian lain mengenai gabor filter dan pengenalan wajah juga dilakukan oleh [5]. dan kawan-kawan yang mana melakukan penelitian pengembangan gabor filter pada pengenalan wajah dengan judul penelitian Enhancement of the Face Recognition Using Gabor Filterdimana pada penelitian ini mereka menyajikan sistem biometrik untuk deteksi wajah dan pengenalan pada gambar berwarna. Dalam 40Gabor filter yang berbeda yang diterapkan pada gambar dan akan menghasilkan 40 gambar berbeda dengan orientasi yang berbeda dan membahas algoritma baru untuk mendeteksi fitur wajah dan mengekstrak titik geometris yang sesuai Dalam 40 titik gambar disaring titik intensitas maksimum dihitung dan tandai sebagai poin fidusia. Untuk mengurangi jarak poin Fiducial antara titik-titik tersebut dipertimbangkan. Dengan menggunakan rumus jarak antara titik dikurangi tersebut dihitung, Kemudian jarak antara mereka dibandingkan dengan database yang telah ditentukan sebelumnya Jika jarak itu ada gambar yang sesuai akan dikenali. Jaringan saraf yang digunakan untuk pengenalan wajah didasarkan pada arsitektur Multi Layer Perception (MLP). (Nayak et.al, 2015).

\subsection{Skin Color}

II. Metode Penelitian

Skin Color merupakan warna yang dihasilkan oleh kombinasi dari melanin, hemoglobin, karoten, dan bilirubin [5]. Jumlah melanin mempengaruhi kegelapan dari warna kulit. Warna kulit tergantung pada 3 (tiga) komponen menurut derajat yang bervariasi. Jaringan memiliki warna inheren kekuningan akibat kandungan karoten. Adanya $\mathrm{Hb}$ beroksigen dalamdasar kapiler dari dermis memberinya warna kemerahan. Dan warna kecoklatan sampai kehitaman adalah akibat jumlah pigmen melanin yang bervariasi. Dari ketiga substansi berwarna ini hanya melanin yang dihasilkan di kulit. Melanin adalah produk dari melanosit.

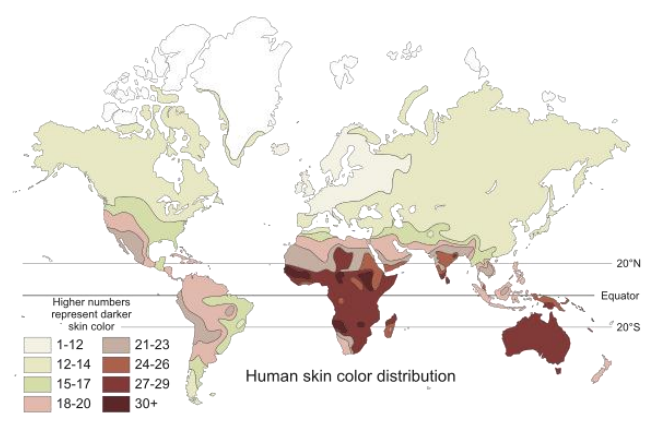

Gambar 1. Sebaran Warna Kulit Di Dunia

\subsection{Skin Model}

Skin Model merupakan kondisi atau kriteria yang digunakan untuk membantu menentukan apakah suatu piksel memiliki nilai warna yang memenuhi syarat sebagai warna kulit atau bukan. Hasil ekstraksi fitur kulit sangat membantu dalam memisahkan anggota tubuh manusia dari objek lain yang terdapat pada citra salah satunya adalah wajah.

Skin Model menggunakan dua kondisi yaitu sebagai berikut :

\section{Kondisi 1 :}

$\mathrm{R}>95$ and $\mathrm{G}>40$ and $\mathrm{B}>20$

$\max \{R, G, B\}-\min \{R, G, B\}>15$

$|R-G|>15$

$\mathrm{R}>\mathrm{G}$ and $\mathrm{R}>\mathrm{B}$

Kondisi 2 : $0.36 \leq \frac{R}{R+G+B} \leq 0.465$ et $0.28 \leq \frac{G}{R+G+B}$
$\leq 0.363$

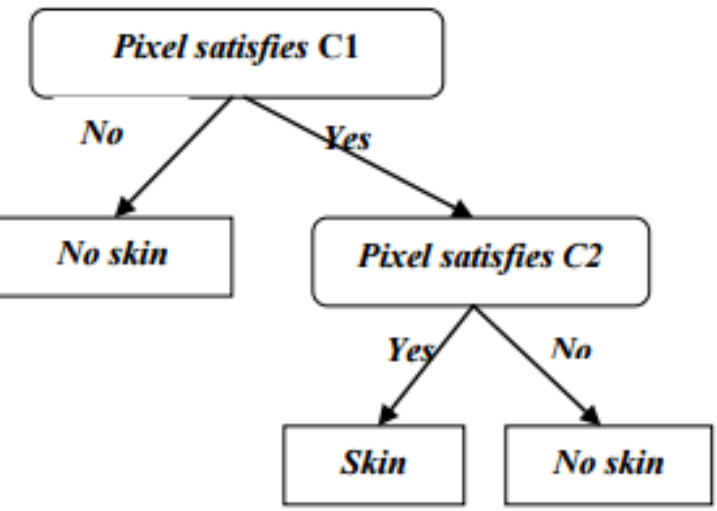

Gambar 2. Diagram Seleksi Skin Model

\subsection{Gabor Filter}

Tahap ekstraksi ciri bertujuan untuk mendapatkan informasi penting dari tekstur suatu citra. Teknik ekstraksi ciri menggunakan fungsi gabor dengan mengekstrak ciri dari citra yang ternormalisasi. Filter gabor merupakan sebuah 
pilihan tradisional untuk memperoleh informasi frekuensi yang terlokalisasi. Filter gabor menawarkan lokalisasi simultan terbaik dari informasi frekuensi spasial. Akan tetapi, filter gabor memiliki dua keterbatasan utama, bandwidth maksimum sebuah filter gabor terbatas pada sekitar satu oktaf dan tidak optimal jika digunakan untuk mencari informasi spektral yang luas dengan lokalisasi spasial yang maksimal.

Setiap landmark dari wajah direpresentasikan dengan respon-respon filter gabor. Filter gabor 2D diperoleh dengan memodulasi gelombang sinus 2D pada frekuensi dan orientasi tertentu dengan Gaussian envelope. Fungsi 2D filter gabor meminimalisasi ciri yang tidak penting dalam kawasan spasial dan frekuensi. Fungsi dasar 2D gabor didefinisikan persamaan sebagai berikut.

$$
\psi_{f, \theta^{(x, y)}}=\exp \left[-\frac{1}{2}\left\{\frac{x_{\theta_{n}}^{2}}{\sigma_{x}^{2}}+\frac{y_{\theta_{n}}^{2}}{\sigma_{y}^{2}}\right\}\right] \exp \left(2 \pi f x_{\theta_{n}}\right)
$$

Persamaan untuk $\sigma \mathrm{x}$ dan $\sigma \mathrm{y}$ adalah standard deviasi Gaussian envelope sepanjang dimensi $\mathrm{x}$ dan $y$, sedangkan $f$ adalah pusat frekuensi gelombang sinusoidal bidang, dan $\theta$ n orientasi. Rotasi bidang $\mathrm{x}-\mathrm{y}$ oleh sudut $\theta \mathrm{n}$ akan menghasilkan filter gabor pada orientasi $\theta \mathrm{n}$. Sudut $\theta$ n didefinisikan sebagai berikut

$$
\theta_{n}=\frac{\pi}{p}(n-1)
$$

Nilai $n=1,2, \ldots, p$ dimana $p$ menunjukkan jumlah orientasi. Desain filter gabor dilakukan dengan tuning filter oleh frekuensi bandpas spasial tertentu dan orientasi dengan tepat memilih parameter filter, penyebaran filter $\sigma \mathrm{x}, \sigma \mathrm{y}$, radial frekuensi f dan orientasi $\theta$ n filter.

\section{Hasil dan Pembahasan}

Prosedur atau tahapan dalam proses identifikasi wajah pada citra digital terdiri dari beberapa tahapan yang dapat dilihat pada gambar 3 berikut.

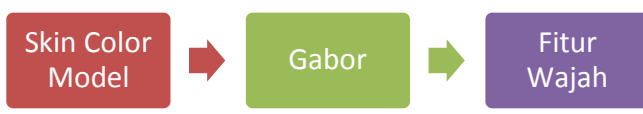

Gambar 3. Diagram prosedur identifikasi wajah.

Pada gambar 3 dapat dilihat bahwa proses identifikasi wajah pada citra digital pada penelitian ini diawali dengan penerapan metode Skin Color Model pada citra digital untuk memperoleh citra dengan objek yang memiliki warna kulit terekstraksi. Tahapan ini bertujuan untuk memisahkan objek yang memiliki warna kulit yaitu manusia dengan objek-objek lain pada citra digital.

Proses dilanjutkan dengan tahapan binerisasi, tahapan ini merubah pixel warna pada citra hasil Skin Color Model menjadi citra grayscale untuk diproses lebih lanjut. Tahapan berikutnya adalah proses konvolusi terhadap filter gabor untuk memperoleh fitur wajah.

Pada dasarnya metode skin color model adalah metode yang menyeleksi piksel dengan warna kulit menggunakan kondisi yang ditentukan. Setiap pixel pada citra akan didata dan diperiksa persyaratan warna piksel nya menggunakan dua kondisi skin color model untuk melihat apakah piksel tersebut memenuhi syarat sebagai piksel kulit atau tidak. Sebagai bahan analisis piksel citra yang digunakan adalah potongan piksel yang diperoleh dari citra wajah seperti yang terlihat pada gambar 4 berikut.

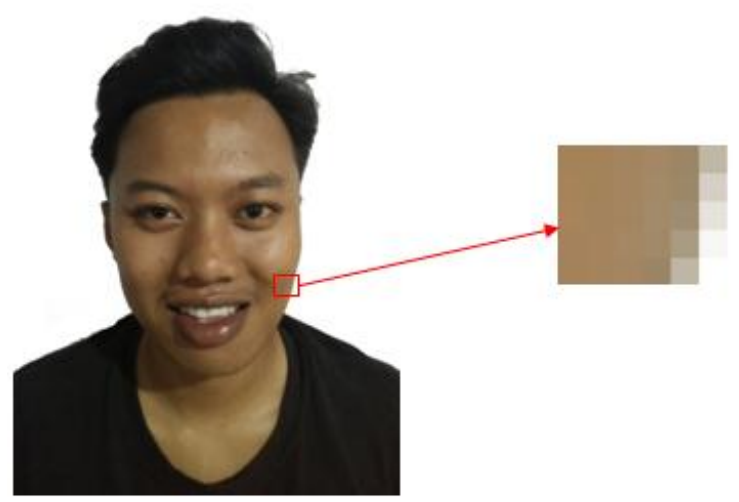

Gambar 4. Contoh piksel wajah

Dari potongan piksel wajah diatas maka dapat diperoleh matriks warna piksel seperti yang dapat dilihat pada tabel 1 berikut.

Tabel 1. Matriks piksel wajah

\begin{tabular}{|l|l|l|l|l|l|}
\hline $165,131,88$ & $164,131,91$ & $163,133,95$ & $164,136,101$ & $157,134,103$ & $193,183,167$ \\
\hline $165,131,88$ & $164,131,91$ & $163,133,95$ & $164,136,101$ & $157,134,103$ & $255,255,255$ \\
\hline $165,131,88$ & $164,131,91$ & $163,133,95$ & $164,136,101$ & $193,183,167$ & $255,255,255$ \\
\hline $165,131,88$ & $164,131,91$ & $163,133,95$ & $157,134,103$ & $193,183,167$ & $255,255,255$ \\
\hline $165,131,88$ & $164,131,91$ & $164,136,101$ & $193,183,167$ & $255,255,255$ & $255,255,255$ \\
\hline
\end{tabular}

Berikut tahap - tahap dalam penyeleksian piksel kulit. 
Himpunan warna pada piksel citra :

$\{165,131,88\},\{164,131,91\},\{163,133,95\}$, $\{164,136,101\},\{193,183,167\},\{157,134$, $103\},\{255,255,255\}$

Pemeriksaan warna kulit pada Piksel $(165,131$, 88) :

Kondisi 1 :

$\mathrm{R}>95=$ memenuhi

$\mathrm{G}>40=$ memenuhi

B $>20=$ memenuhi

$\operatorname{Max}\{R, G, B\}=165$

$\operatorname{Min}\{R, G, B\}=88$

$\operatorname{Max}\{\mathrm{R}, \mathrm{G}, \mathrm{B}\}-\operatorname{Min}\{\mathrm{R}, \mathrm{G}, \mathrm{B}\}=165-88=77>$

$15=$ memenuhi

$|\mathrm{R}-\mathrm{G}|=165-131=34>15=$ memenuhi

$\mathrm{R}>\mathrm{G}$ dan $\mathrm{R}>\mathrm{B}=$ memenuhi

Kondisi 2 :

$\frac{R}{R+G+B}=\frac{165}{165+131+88}=0.4297$
$\frac{G}{R+G+B}=\frac{131}{165+131+88}=0.3411$

Kondisi 2 memenuhi persamaan :

$0.36 \leq \frac{R}{R+G+B} \leq 0.465$ et $0.28 \leq \frac{G}{R+G+B}$ $\leq 0.363$

Sehingga dapat dikatakan bahwa $\{165,131,88\}$ merupakan piksel kulit.

Pemeriksaan warna kulit pada Piksel $\{164,131$, 91\} :

Kondisi 1 :

$\mathrm{R}>95=$ memenuhi

$\mathrm{G}>40=$ memenuhi

B $>20=$ memenuhi

$\operatorname{Max}\{R, G, B\}=164$

$\operatorname{Min}\{R, G, B\}=91$

$\operatorname{Max}\{R, G, B\}-\operatorname{Min}\{R, G, B\}=164-91=73>$ $15=$ memenuhi

$|\mathrm{R}-\mathrm{G}|=164-131=33>15=$ memenuhi

$\mathrm{R}>\mathrm{G}$ dan $\mathrm{R}>\mathrm{B}=$ memenuhi

Kondisi 2 :

$\frac{R}{R+G+B}=\frac{164}{164+131+91}=0.4249$
$\frac{G}{R+G+B}=\frac{131}{164+131+91}=0.3393$

Kondisi 2 memenuhi persamaan :

$$
0.36 \leq \frac{R}{R+G+B} \leq 0.465 \text { et } 0.28 \leq \frac{G}{R+G+B}
$$

Sehingga dapat dikatakan bahwa $\{164,131$, 91 \}merupakan piksel kulit.

Pemeriksaan warna kulit pada Piksel $\{157,134$, $103\}$ :

Kondisi 1 :

$\mathrm{R}>95=$ memenuhi

$\mathrm{G}>40=$ memenuhi

$\mathrm{B}>20=$ memenuhi

$\operatorname{Max}\{R, G, B\}=157$

$\operatorname{Min}\{R, G, B\}=103$

$\operatorname{Max}\{\mathrm{R}, \mathrm{G}, \mathrm{B}\}-\operatorname{Min}\{\mathrm{R}, \mathrm{G}, \mathrm{B}\}=157-103=54>$

$15=$ memenuhi

$|\mathrm{R}-\mathrm{G}|=157-134=23>15=$ memenuhi

$\mathrm{R}>\mathrm{G}$ dan $\mathrm{R}>\mathrm{B}=$ memenuhi

Kondisi 2 :

$\frac{R}{R+G+B}=\frac{157}{157+134+103}=0.3985$
$\frac{G}{R+G+B}=\frac{134}{157+134+103}=0.3401$

Kondisi 2 memenuhi persamaan :

$0.36 \leq \frac{R}{R+G+B} \leq 0.465$ et $0.28 \leq \frac{G}{R+G+B}$ $\leq 0.363$

Sehingga dapat dikatakan bahwa $\{157,134$, 103 \}merupakan piksel kulit.

Pemeriksaan warna kulit pada Piksel $\{255,255,255\}$ :

Kondisi 1 :

$\mathrm{R}>95=$ memenuhi

$\mathrm{G}>40=$ memenuhi

$\mathrm{B}>20=$ memenuhi

$\operatorname{Max}\{R, G, B\}=255$

$\operatorname{Min}\{R, G, B\}=255$

$\operatorname{Max}\{\mathrm{R}, \mathrm{G}, \mathrm{B}\}-\operatorname{Min}\{\mathrm{R}, \mathrm{G}, \mathrm{B}\}=255-255=0>$ $15=$ tidak memenuhi

$|\mathrm{R}-\mathrm{G}|=255-255=0>15=$ tidak memenuhi

$\mathrm{R}>\mathrm{G}$ dan $\mathrm{R}>\mathrm{B}=$ tidak memenuhi

Dikarenakan pemeriksaan kondisi 1 banyak persyaratan yang tidak memenuhi maka dapat langsung diambil kesimpulan bahwa piksel $\{255,255,255\}$ bukanlah piksel kulit.

Berdasarkan komputasi persyaratan warna kulit diatas maka dapat disusun tabel himpunan warna dan hasil pemeriksaan warna kulitnya pada tabel 2 berikut : 
Tabel 2. Hasil Pemeriksaan Piksel Kulit

\begin{tabular}{|l|l|l|}
\hline No. & Piksel & Hasil \\
\hline 1 & $\{165,131,88\}$ & Kulit \\
\hline 2 & $\{164,131,91\}$ & Kulit \\
\hline 3 & $\{163,133,95\}$ & Kulit \\
\hline 4 & $\{164,136,101\}$ & Kulit \\
\hline 5 & $\{193,183,167\}$ & Kulit \\
\hline 6 & $\{157,134,103\}$ & Kulit \\
\hline 7 & $\{255,255,255\}$ & Bukan Kulit \\
\hline
\end{tabular}

Pada tampilan halaman pembuka, terdapat informasi mengenai penulis dan judul dari sekali muncul pada saat aplikasi dijalankan. Adapun tampilan dari halaman pembuka dapat dilihat pada gambar berikut :

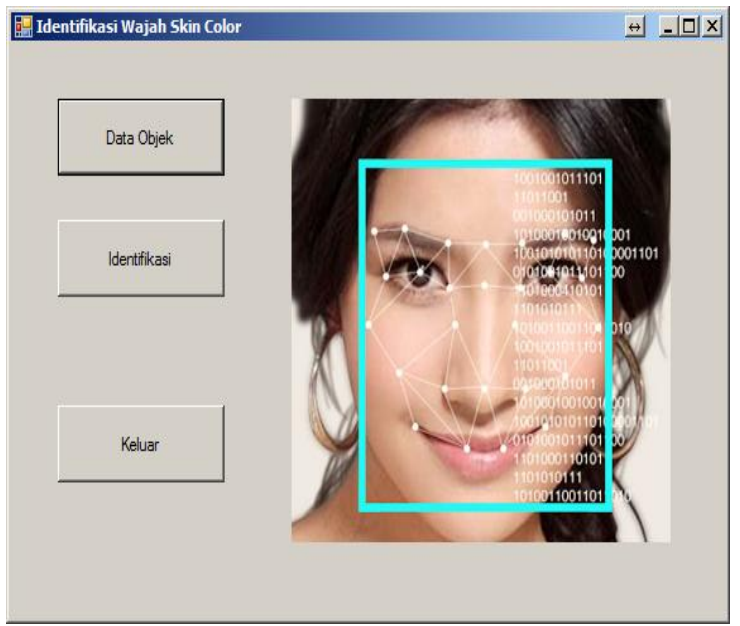

Gambar 5. Tampilan Depan Aplikasi

Form utama seperti yang terlihat pada gambar 5. merupakan form yang dikembangkan sebagai antarmuka penghubung ke form-form lainnya. Form utama memiliki tiga navigasi utama yaitu menu data wajah dan menu identifikasi.

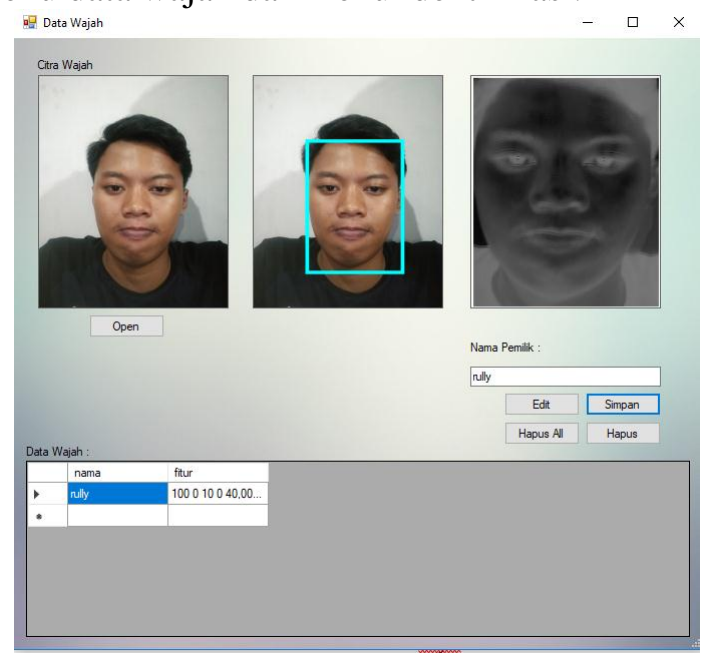

Gambar 6. Form Data Wajah
Form data wajah seperti yang terlihat pada gambar 6. memiliki fitur untuk melakukan perubahan nama wajah yang sudah terdaftar pada database. Wajah-wajah yang terdaftar pada antarmuka data wajah ini merupakan data-data wajah yang diperoleh dari proses ekstraksi fitur menggunakan metode Skin Color dan Ekstraksi fiter Gabor.

Form data wajah memiliki fitur untuk membuka citra yang memiliki wajah untuk dikenali oleh aplikasi yang dibangun. Informasi piksel yang menyusun wajah pada citra digital input akan diseleksi menggunakan algoritm skin color model dengan melakukan klik pada tombol "Simpan". Informasi seleksi kemudian digunakan untuk diproses lebih lanjut menggunakan filter gabor untuk memperoleh fitur gabor yang akan digunakan untuk proses identifikasi pada wajah. adapun contoh hasil ekstraksi dan seleksi menggunakan metode Skin Color dengan Gabor dapat dilihat pada gambar berikut.

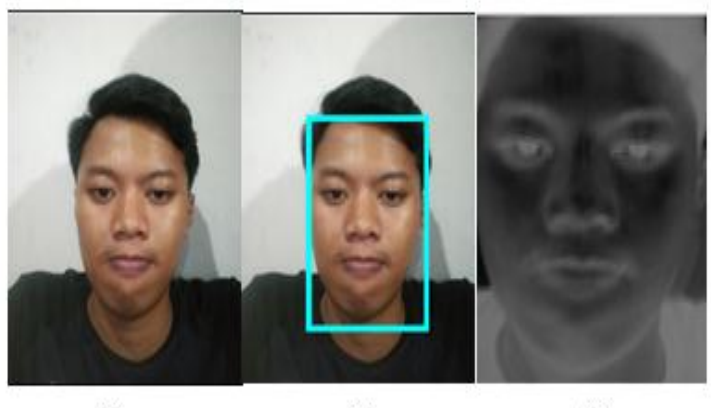

(a)

(b)

Gambar 7. Proses Ekstraksi Fitur (a) Citra Wajah Input, (b) Seleksi Menggunakan Skin Color, (c) Hasil Filter Gabor

Proses ekstraksi fitur seperti yang terlihat pada gambar 7. dapat dilihat tahapan proses ekstraksi citra wajah dari citra input. Citra input (a) adalah citra yang di-input oleh pengguna untuk di ekstraksi fitur nya. Citra (b) merupakan hasil segementasi hasil seleksi menggunakan metode Skin Color, dan (c) merupakan citra hasil ekstraksi gabor yang mana rasio antar piksel gelap dan piksel terang dari area - area pada hasil filter gabor yang kemudian disimpan ke dalam database beserta pemilik wajah dari citra input seperti yang terlihat gambar 7 . 


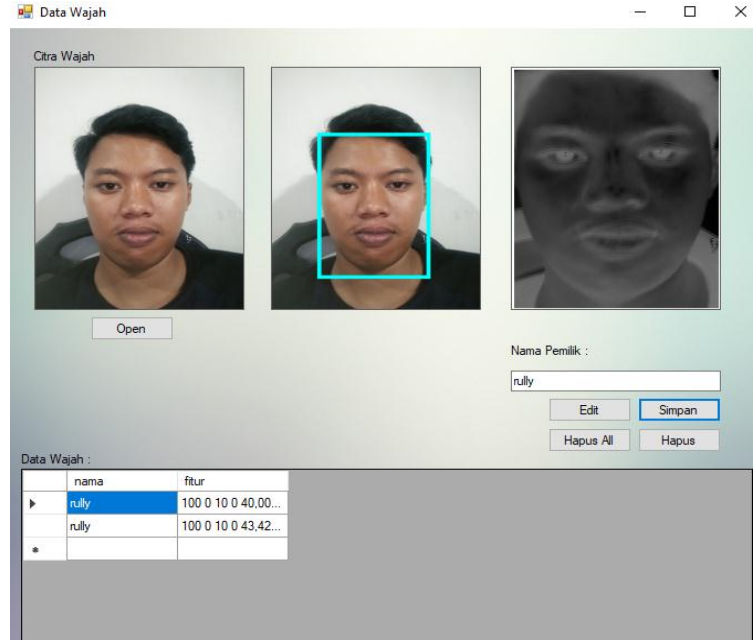

Gambar 8. Penyimpanan Fitur Citra Wajah

Implementasi dilanjutkan dengan melakukan identifikasi citra uji menggunakan Form Identifikasi. Form Identifikasi memiliki fitur untuk membaca fitur gabor yang diperoleh dari citra wajah yang di-input. Adapun tampilan dari Form Identifikasi dapat dilihat gambar 8.

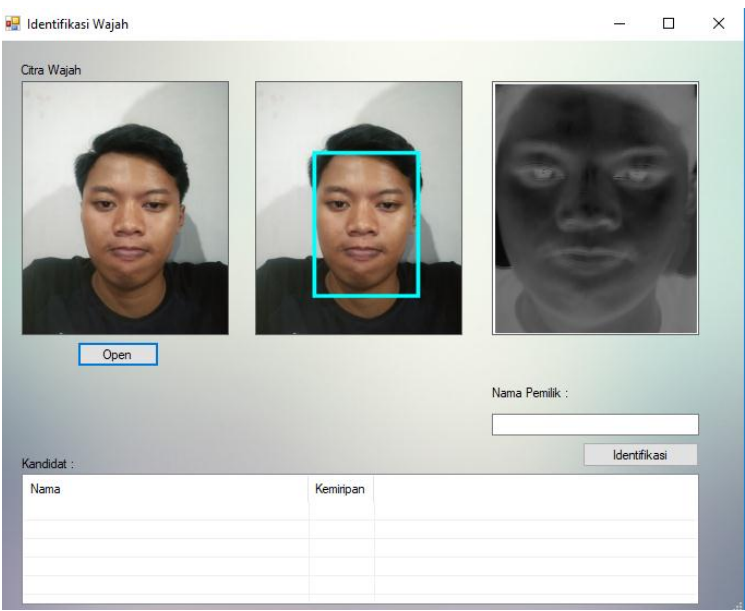

Gambar 9. Implementasi Form Identifikasi

Tahapan dari proses identifikasi dari tampilan Form Identifikasi secara umum mirip dengan tahapan proses dari pendataan wajah. Citra input pertama sekali diseleksi menggunakan metode Skin Color Model sehingga menghasilkan area wajah dari citra input. Area wajah tersebut kemudian di proses lebih lanjut menggunakan filter Gabor. Hasil ekstraksi Gabor kemudian dibandingkan dengan fitur wajah yang terdata di database seperti yang terlihat pada gambar 9 berikut.

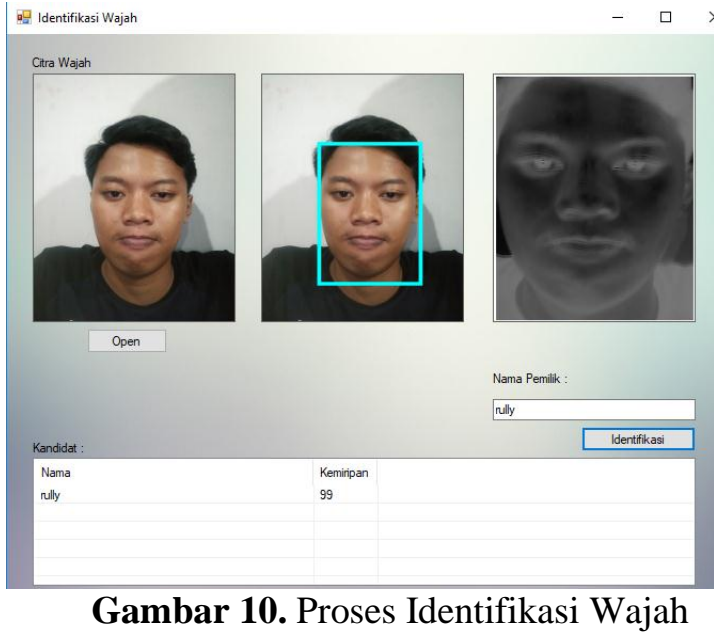

Pada gambar 10 dapat dilihat proses identifikasi wajah yang mana menampilkan hasil nama pemilik beserta kandidat - kandidat lain dengan nilai kemiripannya. Proses identifikasi menggunakan nilai minimal kemiripan sebesar $65 \%$. Data wajah dari database akan dihitung kemiripan fitur nya dengan fitur dari citra uji. Identitas dengan kemiripan tertinggi akan dipilih namun jika tidak ada pemilik yang memiliki kemiripan minimal 65\% maka hasil identifikasi akan menghasilkan pesan "Tidak Diketahui”.

\subsection{Pengujian}

Pengujian dilakukan untuk memperoleh validasi implementasi algoritma skin color model dan Gabor pada pengembangan sistem identifikasi wajah pada citra digital. Adapun tujuan utama dari kegiatan pengujian adalah untuk memperoleh kemampuan dari Skin Color Model dan Gabor dalam proses identifikasi wajah pada citra digital.

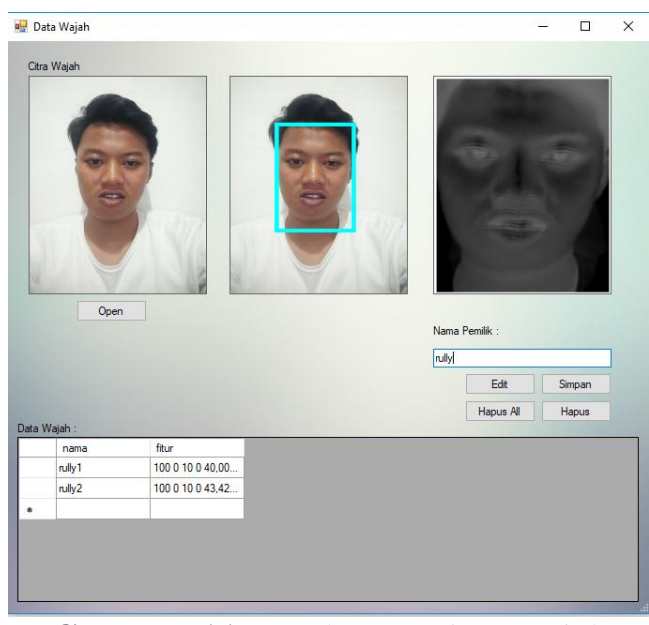

Gambar 11. Pendataan Citra Wajah

Setelah proses pendataan wajah dilakukan, pengujian dilanjutkan dengan 
mengidentifikasi wajah yang telah di data seperti yang terlihat pada gambar 4.8 :

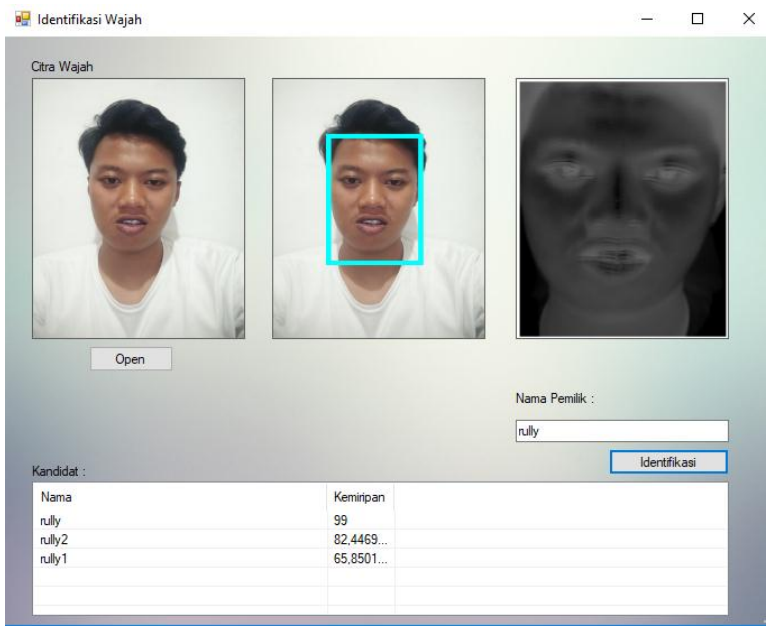

Gambar 12. Hasil Identifikasi Citra Wajah Rully

Citra wajah Rully berhasil di-identifikasi dengan baik dimana kemiripan dengan citra yang ada dapat dilihat bahwa dengan citra memiliki kemiripan 99\% yang di-ikuti dengan citra Rully2 dengan tingkat kemiripan sebesar 82,44 persen. Pengujian kemudian dilanjutkan dengan mengidentifikasi citra yang belum pernah didata pada pendataan wajah seperti yang terlihat pada gambar 12 :

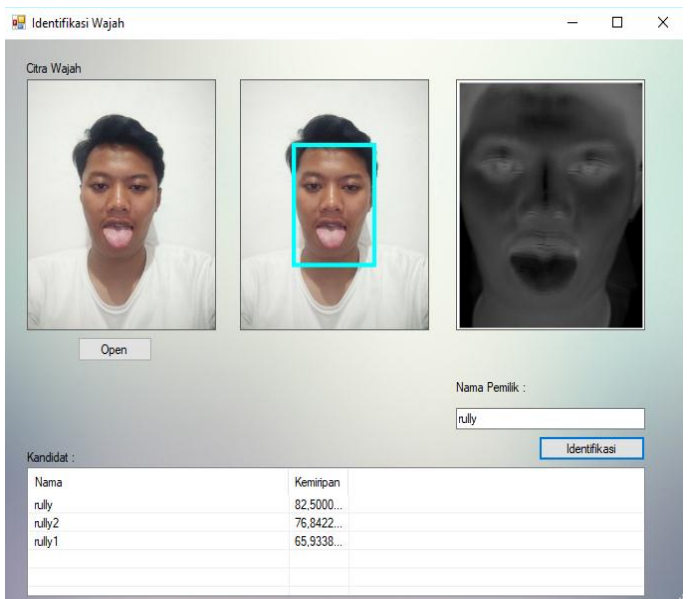

Gambar 13. Pengujian Citra Wajah Yang Belum Di Data

Pengujian citra wajah yang belum didata pada pendataan wajah seperti yang terlihat pada gambar 13 menunjukkan hasil identifikasi "Rully" dikarenakan beberapa fitur dari citra wajah yang belum didata memiliki kemiripan dengan fitur wajah yang sudah pernah didata sehingga akan ditampilkan identitas wajah dengan yang paling mirip. Seperti yang terlihat pada gambar 4.9 identitias yang paling mirip dengan citra tersebut adalah "Rully".

Tabel 3. Hasil Pengujian

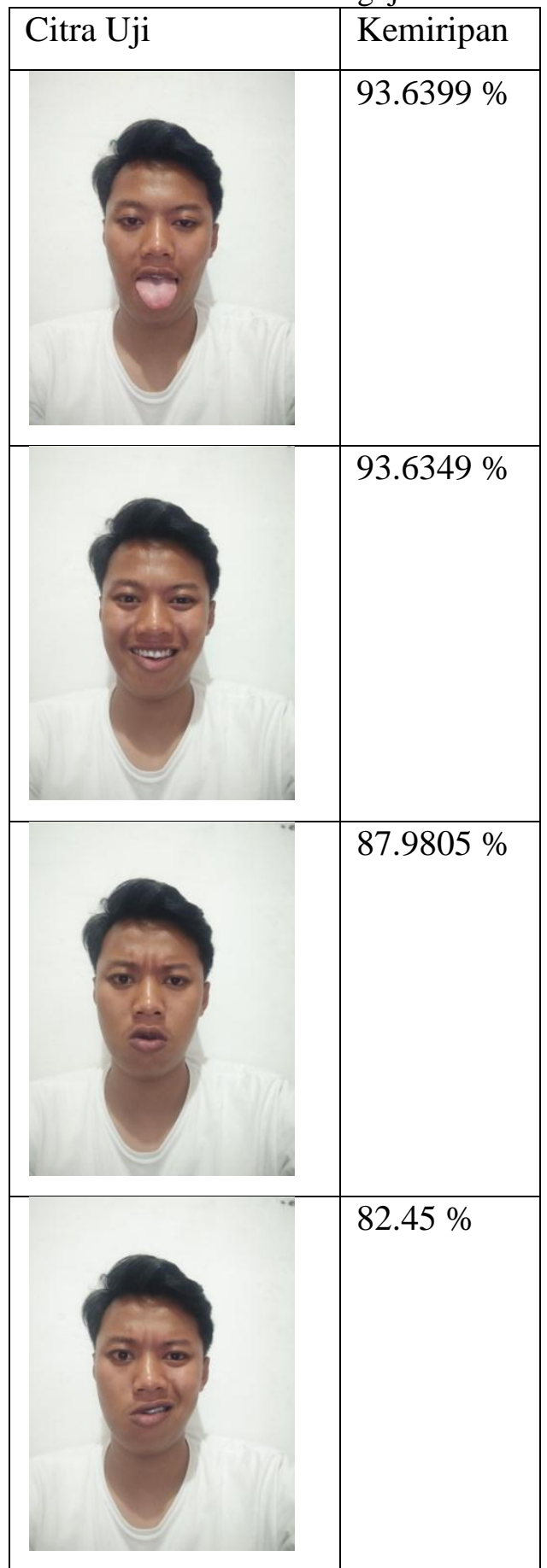

Dari hasil yang diperoleh, dapat dilihat bahwa program sistem identifikasi wajah pada citra digital menggunakan metode Skin Color Model dan Gabor yang dibangun dapat memberikan hasil yang cukup baik dimana baik pada citra yang sama maupun berbeda aplikasi masih dapat mengidentifikasi wajah dari citra yang di-input. 
Adapun akurasi yang diperoleh cukup baik dimana rata-rata akurasi terendah berkisar $82.45 \%$ dan tertinggi $93.6349 \%$.

\section{Kesimpulan dan Saran}

\subsection{Kesimpulan}

Berdasarkan hasil uji coba dan pembahasan program yang dilakukan, maka dapat di tarik kesimpulan yaitu :

1. Identifikasi wajah manusia dengan cepat dan akurat dengan menggunakan Gabor Filter dan Skin Model pada penelitian dilakukan dengan melakukan seleksi piksel citra menggunakan Skin Model sehingga dapat diperoleh informasi area wajah yang terpisah dengan area objek lainnya pada yang mana area tersebut di proses lebih lanjut menggunakan Gabor Filter untuk di ekstraksi fiturnya. Kombinasi kedua metode tersebut menghasilkan proses yang lebih cepat dimana pada ekstraksi Gabor Filter tidak semua piksel dari citra yang diproses melainkan hanya area wajah hasil seleksi Skin Color Model_sehingga proses menjadi lebih cepat dibandingkan dengan memproses keseluruhan piksel dari citra.

2. Hasil pengujian yang telah dilakukan dapat dilihat kombinasi metode Skin Color Model dan Gabor Filter memberikan hasil identifikasi yang cukup baik dimana fitur gabor. Namun perbedaan pencahayaan dan jarak capture yang signifikan dapat mempengaruhi hasil akurasi dari identifikasi.

\subsection{Saran}

Saran-saran yang penulis kemukakan diharapkan dapat lebih meningkatkanhasil yang telah didapatkan. Berikut beberapa saran yang disampaikan oleh penulis :

1. Proses identifikasi membutuhkan sumberdaya komputasi yang besar sehingga direkomendasikan spesifikasi komputer yang cukup baik.

2. Penelitian yang akan datang diharapkan dapat mengkombinasikan dengan metodemetode tambahan lainnya sehingga fitur yang diekstraksi dapat lebih spesifik dan menghasilkan akurasi yang lebih baik.

\section{Daftar Pustaka}

[1] Wetzstein, G. (2013). Digital Image Processing EE368/CS232. Department of Electrical Engineering Stanford University.
[2] Hajraoui, A., \& Sabri, M. (2014). Face Detection Algorithm based on Skin Detection, Watershed Method and Gabor Filters. International Journal of Computer Applications (0975 - 8887), Vol 94, No 6.

[3] Girod, B. (2014). Digital Image Processing. Stanford University.

[4] Gopika, B., Srilaxmi, K., Alekhya, D., Rao, B., \& Mohan, B. (2015). Face Recogition by Using Gabor Feature Extraction and Neural Networks. IOSR Journal of Electronics and Communication Engineering (IOSR-JECE), e-ISSN: 22782834,p- ISSN: 2278-8735. Volume 10, Issue 2.

[5] Nayak, R., Pathak, D. R., \& Kumar, A. (2015). Enhancement of the Face Recognition Using Gabor Filter. (IJCSIT) International Journal of Computer Science and Information Technologies, Vol. 6 (1). 